\title{
PROVIDING COMPENSATION FOR THE DETRIMENT CAUSED BY CRIME WHEN REFERRING CRIMINAL CASES TO COURT IN THE RUSSIAN CRIMINAL PROCEEDINGS
}

\author{
${ }^{1}$ Dmitriy Ivanov \\ ${ }^{2}$ Sergey Khmelev \\ 3 Irina Gubko \\ ${ }^{4}$ Alexander Gaevoy \\ 5 Yulia Gorlova
}

\begin{abstract}
Objective: The objective of the research is to consider topical issues related to the content of the final procedural documents (indictments) for the presence in them of full information about the persons who have become victims of criminal acts, as well as the nature and amount of detriment caused to them.
\end{abstract}

Method: Authors used special legal methods: analysis, synthesis and sociological methods: questioning, conversation and interviewing. The application of methods of analysis and synthesis real information was obtained regarding the effectiveness of the activities of the investigator and the interrogator in ensuring compensation for detriment caused by crime when making a procedural decision to send a criminal case to court.

Results: The authors substantiate the position on the need to obligatorily serve the victim and their representative with an indictment in order to provide the latter with all the necessary information to substantiate claims for compensation for detriment caused by crime in the course of further consideration of the criminal case on the merits at the hearing.

Conclusions: The victim and his representative must receive copies of the indictment in order to have all the necessary information, including those directly related to the issues of compensation for harm caused by the crime, in order to participate in the court session.

Keywords: Investigator. Victim. Detriment caused by a crime. Criminal Complaint.

Received: 06/01/2021

Accepted: 21/04/2021

DOI: https://doi.org/10.37497/revcampojur.v9i2.748

\footnotetext{
${ }^{1}$ Moscow State Institute of International Relations (University) of the Ministry of Foreign Affairs of the Russian Federation (MGIMO-University), (Russia). E-mail: dmitriy.a.ivanov@bk.ru Orcid id: https://orcid.org/0000-0002-2023-3771

${ }^{2}$ Moscow University of the Ministry of Internal Affairs of Russia named by V.Ya. Kikot, (Russia). E-mail: khmelev.s.a@bk.ru Orcid id: https://orcid.org/0000-0003-3281-8045

3 The North Caucasus Branch of the Russian State University of Justice, (Russia). E-mail: gubko.i.v@yandex.ru Orcid id: https://orcid.org/0000-0001-5261-9444

${ }^{4}$ The North Caucasus Branch of the Russian State University of Justice, (Russia). E-mail: sgaevoy@ bk.ru Orcid id: https://orcid.org/0000-0002-4134-3101

${ }^{5}$ Moscow University of the Ministry of Internal Affairs of Russia named by V.Ya. Kikot, (Russia). E-mail: gorlova.yu.a@yandex.ru Orcid id: https://orcid.org/0000-0001-8418-991X
} 


\section{INDENIZAÇÃO PELO PREJUÍZO CAUSADO PELO CRIME AO ENCAMINHAR CASOS CRIMINAIS AO TRIBUNAL NO PROCESSO CRIMINAL RUSSO}

\section{RESUMO}

Objetivo: O objetivo da pesquisa é considerar questões atuais relacionadas ao conteúdo das peças processuais finais (acusações) para a presença nelas de informações completas sobre as pessoas que se tornaram vítimas de atos criminosos, bem como a natureza e o valor do prejuízo causado a eles.

Método: Os autores utilizaram métodos jurídicos especiais: análise, síntese e métodos sociológicos: questionamento, conversação e entrevista. Com a aplicação de métodos de análise e síntese obteve-se informação real sobre a eficácia das atividades do investigador e do interrogador na garantia de indemnizações por danos causados pelo crime na tomada de decisão processual de envio de um processo criminal a tribunal.

Resultados: Os autores fundamentam a posição sobre a necessidade de obrigatoriamente intimar a vítima e o seu representante de forma a fornecer-lhe todas as informações necessárias à fundamentação de pedidos de indemnização por danos causados pelo crime no decurso da apreciação do processo. processo criminal sobre o mérito na audiência.

Conclusões: A vítima e o seu representante devem receber cópias da acusação para dispor de todas as informações necessárias, incluindo as directamente relacionadas com as questões de indemnização dos danos causados pelo crime, para poderem participar na sessão do tribunal.

Palavras-chave: Investigador. Vítima. Prejuízo causado por um crime. Denúncia Criminal.

\section{INTRODUCTION}

Analysis of the materials of the investigative and judicial practice allows us to conclude that the success of the investigation of any criminal offense depends, as a rule, on the professional skill of the investigator, the interrogator and their ability to effectively organize work on the criminal cases in their production.

After examining the materials of the criminal case, evaluating all the collected evidence and finding it sufficient for drawing up an indictment, the investigator proceeds to the final stage of the preliminary investigation.

Arguing about the completeness of the materials of the criminal case and the proof of the fact of the crime committed before sending the criminal case to the prosecutor for the approval of these procedural documents through the prism of achieving the goal we are investigating compensation for detriment caused by crime - the authors develop a tendency to prove a number of circumstances included in the subject of proof (Art. 73 of the Criminal Procedure Code of the Russian Federation), directly affecting the completeness of the preliminary investigation. 
In this aspect, N.E. Martynenko reasonably asserts that "the legitimate interests of the victim are reduced not only to receiving compensation for the detriment caused; they are associated with resolving issues about the proof of the charge, its volume, the application of the criminal law and the imposition of punishment" (Martynenko, 2015, p. 23).

Developing the point of N.E. Martynenko we deem it necessary to supplement our argumentation with the judgment that the fact of compensation for detriment caused by a crime should additionally correlate with such important circumstances that make it possible to make a decision on sending a criminal case to court such as: establishing the nature and amount of detriment caused by crime; establishing the ownership of the property that has become the subject of criminal encroachment to a specific legal owner; the presence of circumstances mitigating the punishment when establishing a specific form of making amends for the detriment caused; circumstances confirming that the property subject to confiscation in accordance with Art. 104.1 of the Criminal Code of the Russian Federation seized; proof of the claims stated by the plaintiff.

In our opinion, the investigation of the circumstance confirming that the property subject to confiscation seized, necessary to dwell on more detail, since the importance of the content and proof of claims in the final procedural documents of the stage of the completion of the preliminary investigation creates tangible guarantees and a real possibility of making a lawful and fair court decision in terms of compensation for detriment to victims of criminal offenses (Ivanov, 2015, p. 47-48).

We hope that this article will contribute to the study of global participation in the improvement of criminal legislation, in particular, ensuring compensation for harm caused by a crime, when making a procedural decision to send a criminal case to court. Using specific legal methods, we aimed to identify the problems that still exist in the area of providing redress and the benefits that the results of our research can bring.

\section{MATERIALS AND METHODS}

The methodological basis for researching the issues of ensuring compensation for detriment caused by crime when making a procedural decision to send a criminal case to court is the subject of the study and is explained by the use of special legal methods: analysis, synthesis and sociological methods (questioning, conversation, interviewing).

Through the application of methods of analysis and synthesis real information was obtained regarding the effectiveness of the activities of the investigator and the interrogator in ensuring compensation for detriment caused by crime when making a procedural decision to send a criminal case to court. 
The use of the formal legal method made it possible to characterize the existing situation associated with a number of problems arising in the practical activities of the investigator and the interrogator to ensure compensation for detriment caused by crime when making a procedural decision to send a criminal case to court, as well as to analyze the identified problems and propose optimal ways to resolve them.

The sociological research method made it possible to obtain real results of empirical research, as well as to analyze, systematize and generalize them.

As a result of the application of this methodology, new knowledge was obtained about the connections and patterns of the activities of the investigator and the interrogator to ensure compensation for detriment caused by crime when making a procedural decision to send a criminal case to court in Russian criminal proceedings, as well as the trends and prospects for its further improvement.

\section{RESULTS AND DISCUSSION}

It should be pointed out that in accordance with Clauses 8, 9 of Art. 220 of the Code of Criminal Procedure of the Russian Federation in the descriptive and motivating part of the indictment, data on the victim, the nature and amount of detriment caused by crime (Clause 8 of Part 1 of article 220 of the Code of Criminal Procedure of the Russian Federation), as well as data on the civil plaintiff and the civil defendant (Clause 9 of Part 1 of Art. 220 of the Criminal Procedure Code of the Russian Federation).

Let us clarify that if the victim is an individual, then their full name, first name, patronymic, date, month, year, place of birth and residence, occupation and place of work, marital status and the presence of dependents should be indicated. At the same time, one should not forget that the nature of the crime can cause moral, physical, property damage and damage to business reputation. In this connection, it is imperative to indicate what type of detriment is specifically inflicted on the victim and its size. Regarding the injured legal entity, one should indicate its exact name and legal address, as well as the nature of the detriment (property or business reputation), its size and the final assessment of detriment to the rights and interests of the organization protected by law (Pushkarev et al., 2020a, p. 244-248).

The requirement of the law on the reflection in the indictment of the information about the victim is a certain guarantee of the latter's right to protect thier legitimate interests, including compensation for the detriment caused. The presence of such information in these procedural documents will contribute to a more complete understanding of the nature and extent of the detriment caused to a specific victim. It should also be noted the importance of the indictment for 
the victim, since these procedural documents serve as a kind of source of information for him to further protect the right to compensation for detriment caused by crime during the consideration of the criminal case by the court on the merits. In particular, for certain categories of crimes, complete information about the victims seems to be especially necessary if the objects of criminal offenses are the life, health, sexual inviolability of the victim, etc. (Efimichev, Efimichev, 2009, p. 178).

The main violations of Clause 8 Part 1 of Art. 220 of the Code of Criminal Procedure of the Russian Federation are: incorrect indication of the data on the victim in the statement of the charge, or the lack of indication in the indictment of data on the amount of detriment caused by crime. In particular, in the indictment drawn up in a criminal case investigated by the SU of the Russian MIA Administration for the Tver' region on the facts of committing crimes under Paragraphs " $a, b, c$ " of Part 2 of Art. 158, Part 2 of Art. 162 and Part 2 of Art. 325 of the Criminal Code of the Russian Federation, one of the violations was the absence in the indictment of information about the civil plaintiff and the civil defendant. Despite the fact that in this criminal case, eight people were recognized as victims, and three of them suffered property, physical and moral detriment. Moreover, we especially note that the fact of causing property damage, as a rule, can be established already at the stage of initiation of a criminal case (statement about the committed crime, protocol of inspection of the scene, explanation of the victim). At the same time, during the preliminary investigation, the victim may not file a civil claim, since he has the right to do so in court. However, the fact of causing physical and moral detriment to the victim during the preliminary investigation can only be proven if there is a civil claim and the victim is recognized as a civil plaintiff. In this connection, a natural question arises, why is there no data on the civil plaintiff and the civil defendant in the indicated indictment.

It is possible to draw only one very sad conclusion, indicating that the investigator did not pay due attention to the issues of compensation for detriment caused by crime, apparently mistakenly believing that this is the prerogative of the court, especially when it comes to new legal relations in the field of cryptocurrency circulation (Pushkarev et al., 2020b, p. 330-335). Naturally, we note that such assumptions are a significant drawback of the proving process as a whole, and reduce not only the indicators relative to the total amounts of compensated detriment, but undermine the authority and level of public confidence in the bodies of the preliminary investigation.

A separate block, according to the well-grounded opinion of E.I. Bordilovsky and O.A. Galustian in this part of the indictment, "provides data on the victim (for each of them), the nature and amount of detriment caused by crime. If material damage has been caused in the case and a civil claim is declared, these facts must be reflected, indicating at the same time detailed information about the amount of the declared civil claim, civil plaintiff, civil defendant, with a mandatory reference to the volumes, sheets of the case containing these data (resolution on recognition as a 
victim, civil plaintiff, civil defendant, information about their representatives, testimonies given during the preliminary investigation by the indicated participants" (Bordilovskiy, Galust'yan, 2004, p. 93).

Another typical example of such violations should be cited. Thus, in a criminal case on charges of V., O. and R. of committing crimes under Paragraph "a" of Clause 2 of Art. 166 and Paragraph "b" of Clause 4 of Art. 158 of the Criminal Code of the Russian Federation, the Municipal Institution "Central District Hospital" was recognized as victims of the case for the total amount of property damage in the amount of 215,727.45 rubles. and Open Joint Stock Company Russian Agricultural Bank (Rosselkhozbank JSC) for a total amount of property damage in the amount of RUB 1,665,481.00. However, a detailed analysis of the indictment in this criminal case shows that the investigator limited himself to obtaining certificates of the value of the stolen property and interrogating representatives of the victims. From the certificate to the indictment, it follows that no civil claim was filed in the criminal case, no measures were taken to secure a civil claim and possible confiscation of property, and there is no information about civil plaintiffs and civil defendants.

In addition to the list of persons to be summoned to the court session, the bill of indictment must be accompanied by a certificate of progress in the criminal case, reflecting the time and nature of the main procedural decisions taken during the preliminary investigation. Among these decisions, this certificate must contain information about a civil claim, measures to ensure a civil claim and possible confiscation of property. In this case, the fact is important, as noted by V.G. Daev that "the data cited are accompanied by links to the sheets of the case containing the relevant materials" (Alekseev, Bastrykin, Daev, 1989, p. 269). Let us supplement what has been said and the arguments that references to the materials of the criminal case containing data on the nature and amount of detriment caused by crime, the measures taken to ensure its compensation are mandatory in view of the provisions of Clause 5 of Art. 220 of the Code of Criminal Procedure of the Russian Federation, and also focus the attention of the judge at the stage of preparation for the court session when resolving issues related to securing a civil claim and possible confiscation of property (Clause 2 of Art. 230 of the Code of Criminal Procedure of the Russian Federation).

At the same time, it should be remembered that the materials of the criminal case related to the victim are grouped separately from the information concerning the civil plaintiff and the civil defendant, however, precede the latter for the convenience of familiarizing the interested parties with them, especially upon subsequent acquaintance with the case of the prosecutor and the judge, if preparing it for further consideration (Koldin, 2004, p. 93).

However, it is reasonable to emphasize that in the course of studying the materials of criminal cases, the authors also identified positive examples in the activities of investigators, 
interrogators on the proper execution of indictments (indictments, indictments) from the perspective of the issues of compensation for detriment caused by crimes. For example, in a criminal case investigated in the SU of the Ministry of Internal Affairs of Russia in the Lipetsk region on charges of G. and T. of committing a crime under Paragraph "a" of Part 2 of Art. 158 of the Criminal Code of the Russian Federation, the indictment contains comprehensive data on the nature and amount of detriment caused by crime: protocol of inspection of the scene of the incident with a photo table; statement of the head of the department for work with assets of the branch "Media Markt Lipetsk 1", "Media-Markt-Saturn LLC", Lipetsk; a certificate from the Media Markt Lipetsk 1 branch of Media-Markt-Saturn LLC, according to which the inventory revealed a shortage of ten Samsung digital cameras, the purchase price of one camera is 3,394 rubles 00 kopecks; resolution on the recognition and admission to the criminal case of material evidence (order to conduct an unscheduled inventory; an inventory act for a commodity group; an inventory act according to specification; consignment note; invoice; bill of lading); the victim's testimony set out in the protocols of the interrogations of the victim's representative; statement of claim in the amount of 33,944 rubles 00 kopecks; a ruling recognizing the victim as a civil plaintiff.

The following is complete information about the victim, the location of the legal entity, the victim's representative, civil plaintiff, civil defendants.

Speaking about the stage of completion of the preliminary investigation by drawing up an indictment through the prism of resolving issues of compensation for detriment caused by a crime, it should be noted that it includes a set of sequential procedural actions aimed at ensuring guarantees of the rights and legitimate interests of victims of crimes.

The mechanism of handing over to the victim and their representative a copy of the indictment is of great importance in the complex of the indicated actions. Let us focus on this aspect in view of the fact that the full amount of information regarding the nature and extent of the detriment caused by crime, information about civil defendants and about the measures taken by the investigator, the inquirer during the preliminary investigation, aimed at ensuring compensation for detriment, is contained in these procedural documents. In this connection, we believe that these procedural documents containing the results of the preliminary investigation must be available to the victim (victim's representative) without fail in order to defend their interests related to compensation for the detriment caused by crime in court.

Russian criminal procedural legislation, in our opinion, does not look ideal in relation to the indicated problem. In particular, from the content of Part 2 of Art. 222, Part 3 of Art. 226 and Part 3 of Art. 226.8 of the Code of Criminal Procedure of the Russian Federation, it follows that after the prosecutor has approved the indictment, copies of these documents with annexes must be handed over only to the accused. At the same time, the provisions of these norms of the criminal procedure 
law establish that copies of these documents are handed to the victim (victim's representative) only at their request, which looks unreasonable and deliberately assigns a secondary role to these participants in criminal proceedings.

In this regard, interesting arguments are expressed by a number of authors, pointing out that the right of the victim to familiarize himself with the materials of the criminal case is an expression of access to justice (Golova, 2014, p. 167). At the same time, we will strengthen the above with the arguments that often the participation of the victim in most criminal cases consists of recognizing him as such, interrogating him as a victim and recognizing him as a civil plaintiff. All the above procedural actions can be carried out by the investigator, the inquirer in relation to the victim (representative of the victim) within one day. Thus, for the entire period of the preliminary investigation, the victim (victim's representative) can visit the investigator, the inquiry officer only once. Naturally, in this case, he practically will not be in control of the situation that developed during the preliminary investigation, including knowing about the measures taken by the investigator, the interrogating officer to ensure compensation for the detriment caused by crime. Considering that the only full-fledged procedural document at the preliminary investigation stage is the indictment, it is extremely necessary for the victim (victim's representative) to have it.

In summary, we consider it appropriate to amend Art. 222 of the Code of Criminal Procedure of the Russian Federation and provide for the mandatory delivery of a copy of the indictment to the victim or thier representative.

\section{CONCLUSIONS}

The authors conclude that the victim and their representative must, like the defense lawyer of the accused, receive copies of the indictment in order to have all the necessary information, including those directly related to the issues of compensation for detriment caused by crime, to participate in the hearing. Only then will the protection of the rights and legitimate interests of persons who have become victims of criminal encroachments in criminal proceedings achieve its goal, and as a result, will increase the effectiveness of the implementation of compensation mechanisms for compensation for the detriment caused by crime.

\section{REFERENCES}

ALEKSEEV, N.S., BASTRYKIN, A.I., DAEV, V.G. (1989). Soviet criminal procedure. Leningrad: Leningrad University Publishing House.

BORDILOVSKIY, E.I., GALUST'YAN, O.A. (2004). Suspension, resumption, termination of a criminal case and the end of the preliminary investigation with an indictment: Textbook. Moscow. 
EFIMICHEV, P.S., EFIMICHEV, S.P. (2009). Investigation of crimes: theory, practice, ensuring the rights of the individual. Moscow: Yustitsinform.

GOLOVA, S.I. (2014). Procedural activity of the investigator to notify the participants in criminal proceedings about the end of the preliminary investigation with an indictment. Society and Law, 3(49), 166-170.

IVANOV, D.A. (2015). The value of developing a mechanism for compensation for harm caused by a crime in pre-trial proceedings in a criminal case. Bulletin of Economic Security of the Ministry of Internal Affairs of Russia, 7, 47-51.

KOLDIN, S.V. (2004). Protection of the rights and legitimate interests of the victim under the Code of Criminal Procedure of the Russian Federation: Diss. Saratov.

MARTYNENKO, N.E. (2015). Criminal legal protection of the victim: abstract of thesis diss. Moscow.

PUSHKAREV, V.V., ARTEMOVA, V.V., ERMAKOV, S.V., ALIMAMEDOV, E.N., POPENKOV, A.V. (2020b). Criminal prosecution of persons, who committed criminal, acts using the cryptocurrency in the Russian Federation. Revista San Gregorio, 42, 330-335.

PUSHKAREV, V.V., BOZIEV, T.O., ESINA, A.S., ZHAMKOVA, O.E., CHASOVNIKOVA, O.G. (2020a). Criminal prosecution for crimes committed in the banking industry. Laplage em Revista, 6(ExtraC), 244-248. 